\title{
Australian Federalism and the Global Economic Crisis of 2008-09
}

\author{
Geoff Anderson \& Alan Fenna
}

Alan Fenna is Professor of Politics at The John Curtin Institute of Public Policy at Curtin University Western Australia.

Geoff Anderson is a Senior Lecturer in the Department Politics and Public Policy at Flinders University South Australia.

The research reported in this article has been in part supported under the Australian Research Council's Discovery funding scheme.

\section{Introduction}

Crises and external threats have almost inevitably a centralising impact on federations. After all, it is generally agreed that federations arose in the first place as a strategic decision to trade-off independence for greater external security and greater internal economic efficiency. We can hypothesise that an event such as the global financial crisis (GFC) and consequent global recession of 2008-09 would be little different. In particular, we would expect it to ratchet up the role of the central government in the federation for a number of reasons. In all federations, the central government has both the responsibility and the tools of macroeconomic management; in addition regulation of the main financial institutions is typically a central government responsibility. Central governments also enjoy broad taxing powers that give them greater fiscal resilience and capacity to respond particularly by way of economic stimulus. Finally, in a national crisis, popular expectations demand a 'national' response and in this instance the strongly international character of the crisis further increased the domestic focus on the government that represents in the global economy.

It was consequently not surprising that the international nature of the crisis, and the fiscal strength needed to combat it, naturally saw the focus for government action squarely fall on the Commonwealth (central) government in Aus- 
tralia and acted to reinforce and legitimise the centralisation which has come to characterise Australian federalism. This was particularly apparent when the Commonwealth was required to support the credit rating of the States in international finance markets.

However, we also note that the crisis confirmed that the residual role of the States remains significant, particularly as regards the longer-term economic reform and productivity agenda of the Commonwealth and the immediate requirement to deliver some of the main elements of the government's countercyclical economic stimulus package. Perversely the crisis also demonstrated the Commonwealth's inability to implement programs on its own account, when going it alone without the States led to serious and embarrassing instances of poor policy design and maladministration. The need to engage with the States also reinforced the collaborative process of the Council of Australian Governments (COAG), ${ }^{1}$ which since its creation in the mid 1990s has become a significant institution of cooperative federalism.

Finally, we identify some unintended consequences of the crisis - which may yet have more significant implications depending on the political make up of the Australian government over the next decade. Commonwealth action to confront the crisis and stimulate the economy resulted in a High Court challenge contesting the government's spending power. It was a challenge the Commonwealth withstood, but the terms of its victory may lead to a referendum to change the Constitution to confirm its power to bypass the States and spend directly in the politically important area of local and regional government and community organisations.

\section{Context: Australian Politics and Federalism}

Prime Minister Kevin Rudd's unprecedented experience at the State level in observing and managing Commonwealth-State relations as a senior adviser to the Queensland State Government, had provided good reason for federalists to expect that as Prime Minister he would lead a government that might act to reverse the centralism in Australian federalism. ${ }^{2}$ This centralism has its roots in the growing financial and economic power of the Commonwealth, but it has accelerated over the past decade in line with realignment of policy positions of the major parties.

In its constitutional structure Australia closely follows the US model, with a single list of enumerated powers of parliament and an allocation of a broad unidentified residual power to the States. Over the twentieth century, judicial

1. The Council of Australian Governments comprises the Prime Minister, the Premiers of the six States and the Chief Ministers of the two Territories.

2. For key relevant characteristics of Australian federalism see Fenna2007a, 2007b, 2008)

L'Europe en formation no3 358 Hiver 2010 - Winter 2010 
interpretation has considerably broadened the application of the enumerated powers. Australian federalism also has an unusually high degree of fiscal centralisation, which has resulted in a very high degree of vertical fiscal imbalance (VFI). The Commonwealth exercises exclusive control over the big three taxes: personal income tax; corporate income tax; and sales tax. Meanwhile, the States rely for their extensive service delivery responsibilities on fiscal transfers, which are split roughly equally between unconditional grant of the entire net national goods and service tax (GST) revenues and a range of conditional grants for specified matters ('Specific Purpose Payments' or SPPs). When the Labor government was elected in November 2007, those specific purpose payments involved the Commonwealth in virtually all areas of State responsibility through over 90 different programs.

Under 11 years of government by the conservative Liberal-National Party coalition ('the Coalition') from 1996 to 2007, further centralisation occurred and with increasing frequency leading ministers, including the Prime Minister, had expressed impatience with the federal system and then outright hostility as one by one, State government fell into Labor Party hands. This fed into a longer-term process of realignment of coalition philosophy regarding federalism. The Liberal Party, the leading party in the Coalition, had been created as the party of federalism expressed in terms of the rights of the states (Summers \& Lowe 2009 152). However, one of the most significant developments in Australian federalism over the past decade has been the move away from an overtly federalist philosophy.

Over its long history, the Australian Labor Party (ALP) has had a complicated and sometimes inconsistent engagement with federalism (Galligan and Mardiste 1992; Parkin and Marshall 1994; Parkin 2003). Despite a record of greater success in winning government at the State level than the Commonwealth "for many decades, there has been a strong tradition in Labor political thought that when political circumstances permitted, the States should be abolished" (Rudd 2005). However, the election of the Rudd government in 2007 in many respects marked the culmination of the transformation of Labor into the party of 'cooperative' federalism. However, it was not cooperation which envisaged any significant return of authority or financial power to the States. Prime Minister Rudd made it clear that he did not subscribe to what he described as the "mindless mantra of States rights"; rather his priority was to address the "dysfunctionality of Federation" as expressed in cost shifting, the 'blame game' between Canberra and the States, and the frustration in the business community and among the general public "about who is responsible for what in our current set of federal arrangements" (Rudd 2005).

Alongside the changes which have reshaped the approach of Australia's political parties has been the growing acceptance that federalism as a political system must pass economic tests in which efficiency and 'seamless' regulation of business 
across the borders of the States are paramount. This view is best represented by the influential Business Council of Australia (BCA) and highlights the increased involvement of corporate Australia in debates on the future structure and operation of the federation. In a major report on federalism the BCA argued it is clear that " $[t]$ he extent of the problems and dysfunctions of the current system offederal-state relations... is such that it has become a major barrier to future prosperity. The challenge of reforming federalism has now become an economic imperative" (BCA 2006). However, this is a theme that extends beyond business organisations and is one that might best be described as "conditional federalism" (Anderson 2008). Based on an assumption that federalism is inherently inefficient - accepted almost without question by Australia's mass media - the continuance of Australia's federal system is regarded as 'conditional' in the sense that it should be maintained as a system of government so long as it meets the conditions necessary for an efficient national economy, regulated by the central government (Anderson 2008: 493-4).

The prospect that Australia would be engulfed by the GFC did not lead to an upsurge in public debate and discussion of federalism. It did, however, lead to warnings by the BCA that federalism should not be allowed to stand in the way of effective action by the central government to defend the national economy. In its submission to the Commonwealth on the 2009-2010 Budget it warned that the global downturn presented a "new challenge to our federation". The BCA noted that a short-term stimulus was needed and that infrastructure spending can be significant in boosting the economy. However, they warned,

the reality is much of the national infrastructure that can be built now is in the hands of the states. It is important the states ensure they do not pull back on useful spending just to avoid running larger temporary deficits. (BCA 2009)

In media reports this translated to 'States damaging PM' with the BCA prescription for insulation the economy described as a call to "bring the Premiers into line" (Franklin 2009).

\section{The Labor Government's Federalism Agenda}

On coming to government in November 2007, Prime Minister Rudd quickly moved to give concrete form to his election commitment to cooperation by elevating the cooperative forum of COAG "into the workhorse of the nation" as the means of "making sure that the States and Territories and the Commonwealth are in harness together" (Rudd 2007). After calling a meeting with the Premiers and Chief Ministers within his first few weeks in office, Rudd instituted a series of quarterly COAG meetings so that by the end of his second year in office, COAG had met nine times. This compares to a mere two in John Howard's first two

L'Europe en formation $n^{\circ} 358$ Hiver 2010 - Winter 2010 
years as Prime Minister and the total of only fourteen meetings during the eleven years of the Howard government. By the time Kevin Rudd stood down as Prime Minister, he had chaired ten meetings of COAG (Anderson 2010).

He also offered a more tangible expression of cooperation by way of a new financial agreement with the States that redrew the architecture of a key mechanism of Commonwealth-State relations. By granting the States greater freedom in how they spend the funds received as Specific Purpose Payments (SPPs) under s96 of the Constitution, the Rudd government brought about a significant pause in the tide of fiscal centralisation implicit in the way the Commonwealth had been using these grants since the early 1970s (Fenna 2008; Anderson 2010).

The COAG process was also central to the government's National Reform Agenda (COAG 2007b). This aimed at enhancing productivity through a major focus on human capital - regarded as the next wave of reform following on from the focus on micro-economic reform in the previous decade. Midway through his first year in office, Kevin Rudd took credit for having "breathed life into the once fractious COAG process" telling the participants "governments are now working together to drive reform and achieve real outcomes for Australia" (Rudd 2008c). His deputy, Julia Gillard, went further. Linking COAG to the an implicit requirement in Australia's Constitution for cooperation to achieve reform, she told her New Zealand counterparts at an Australia New Zealand Leadership Forum in June of 2008, COAG "is becoming a dynamic part of our nation's system of government" (Gillard 2008b) The combination of this commitment to the COAG process, and the positive experience of the initial meetings, meant that COAG was the obvious vehicle for seeking cooperation with the States when the impact of the GFC became apparent.

\section{Impact of the Global Financial Crisis}

Inflation had been the major focus of the Rudd government immediately it assumed office. In the face of gathering financial gloom from the world's financial capitals Wayne Swan, the new Treasurer, had claimed that the crisis would have little impact on Australia because Australian banks were relatively free of the 'toxic assets' which were shaking the foundations of their American counterparts (Wanna 2009: 262). Speaking to journalists two weeks after being sworn in he assured them that the problems associated with sub-prime market were "not directly issues which were experiencing in this country", highlighting instead the "inflationary challenge" which he said needed "a new era of fiscal discipline" (Swan 2007). By March of 2008 it was clear that Australia would not escape these international issues unscathed. Admitting that the global financial market turbulence looked to more prolonged than expected the Treasurer told Parliament on March 18 that 
there was now "no doubt Australia's financial system has been affected by the global financial circumstances" (Swan 2008a).

These sentiments were echoed by Prime Minister Rudd on 27 March when told the annual Economic and Social Outlook Conference that Australia faced "a global financial crisis that poses very significant challenges for the global economy as well as our own" (Rudd 2008a). The government's response to these challenges was to redouble its efforts towards economic reform, enhanced competitiveness and increased productivity. Essential to this reform agenda, as the Treasurer spelt out in his address to the same conference, was "a reinvigorated COAG process" which could "unlock the benefits of Modern Federalism" so that as partners the Commonwealth and the States could overcome the challenges that the world economy presented (Swan 2008b). These speeches by the Prime Minister and his Treasurer followed the COAG meeting in Adelaide on 26 March - which in retrospect was the high water mark of Commonwealth-State relations. The Communiqué for that meeting reported that the heads of government has reached "an historic commitment to a comprehensive new microeconomic reform agenda for Australia" (COAG 2008). The meeting established the framework for the reform of the financial architecture of federalism through the rationalisation of Specific Purpose payments; the creation of new National Partnership programs to provide incentives for further reforms; the commitment to a new Intergovernmental Agreement on Federal Financial Relations; and a new and expanded role for the COAG Reform Council to oversee the reform efforts of both levels of government (COAG 2008).

It was clear from the Communiqué and the speeches of the Prime Minister and the Treasurer at the conference immediately following the meeting, that the Commonwealth saw the agreements reached in Adelaide as embedding the COAG process within its economic reform agenda. The Treasurer was also prepared to place the federation and federalism at the centre of the drive for prosperity and to claim success in "getting federation right, after more than a hundred years of trying". He told the conference that through the reinvigorated COAG process the government was "giving this nation every chance of creating a new generation of prosperity for the future... to build productivity and make the next century of federalism deliver for Australian working families much better than the last" (Swan 2008b). While some funding decisions were made in Adelaide, the bulk of spending commitments would left to be finalised in the COAG meeting planned for November 2008.

As that meeting approached, the global financial crisis - which the government has described first as a challenge and then as a complication (Wanna 2009) - had become a clear source of tension. Two COAG meetings were held in the months leading up to the November meeting at which funding decisions were to 
be announced. Following the October meeting, media reports of a confidential brief on funding options prepared for the States suggested that they were seeking an additional $\$ 23$ billion as the price for signing up to the Prime Minister's COAG Agenda (Taylor 2008). When this was put to Prime Minister Rudd during an interview on $\mathrm{ABC}$ Radio he responded that it was "one of the larger try-ons of the century". He was sure that there would be a lot of what he described as "argy bargy" at the November meeting but, in making it clear that the Commonwealth would call the fiscal tune. Then a week before the premiers and chief ministers met with the Prime Minister, his deputy and minister for education told the Ministerial Council of State and Territory education and training ministers that the National Partnership on Vocational Education and Training (VET) Market Design would not be considered by COAG and that further progress would be based on "understanding the implications of the global financial crisis, the looming recessions in many nations and the implications for Australia's economy" (Gillard 2008a).

It is now known that at the time the Prime Minister was colourfully rejecting the States' demands he was meeting with senior ministers and advisors to put together the first stimulus package to deal with the plunging stock market and the sudden deterioration of the economy evident in the Reserve Bank's decision to slash interest rates (Taylor and Uren 2010: 70-71). On the eve of the COAG meeting the Prime Minister made a statement to the Parliament on the developing crisis. There was no point in 'sugar coating' what was happening he said, the situation was bad and getting worse with the economies of the major developed nations "like dominoes... falling one by one into recession" (Rudd 2008b). However, COAG was to play its part with a "substantial but responsible" $\$ 11$ billion to be offered to the States over four years as the third tranche of the government's plan to invest in stimulating the economy, alongside payments to pensioners and carers, families and home owners (Rudd 2008b).

Just over two months later COAG met again in a special meeting called to consider the Prime Minister's 'Nation Building and Jobs Plan', which was to form the core of the second and more dramatic stage of the action the government took to stimulate the economy. By this stage all attempts to downplay the impact of the global crisis had been abandoned as two days before COAG met the Prime Minister addressed the nation to say that the reality of the global recession had hit home with the potential for massive impact (Rudd 2009a). In determining how to respond the Prime Minister believed that he had absorbed the lessons of past recessions particularly the importance of acting early and decisively along Keynesian lines (Fenna 2010:354). Kevin Rudd was prepared to spend, but inside the government there was significant debate on the question of what to spend that money on (Fenna 2010: 364; Taylor and Uren 2010). The answer was a 
combination of an immediate stimulus of $\$ 12.7$ billion, including an $\$ 8.2$ billion 'Tax Bonus for Working Australians' ${ }^{3}$ and $\$ 42$ billion of largely infrastructure spending under a 'Nation Building and Jobs Plan' (Swan and Tanner 2009). On coming to office the Rudd government had already signalled that large scale infrastructure investment was a priority (Fenna 2010: 363). The COAG meeting in December had established a working group with the objective of "better coordination of infrastructure planning and investment across the nation, across governments and the private sector" and a new body, Infrastructure Australia, to report to COAG on ways to remove blockages to "productive investment in infrastructure" (COAG 2007a). Most of this spending would flow through the States, hence the hastily arranged COAG meeting in early February 2009 to agree on a new National Partnership Agreement (COAG 2009) for the implementation of the Government's stimulus plan.

One program which was to be directed delivered by the Commonwealth was a \$3.9 Billion program to install ceiling insulation which, as the Prime Minister's media release claimed, combined the objective to support jobs with the ambition to "set Australia up for a low carbon future" (Rudd 2009c). This program very soon became beset with problems and was the subject of a damming report that resulted in its rapid termination (see Hawke 2010).

Following the COAG meeting the Prime Minister was generous in his praise for the States and the Territories for meeting at short notice (Rudd 2009b). However, behind the scenes he was apparently "obsessed" with ensuring that his plan be rolled out on time and not "thwarted by problems with the states". (Taylor and Uren 2010: 146) ${ }^{4}$. As a result the National Partnership Agreement established an 'Oversight Group' within the Department of the Prime Minister and Cabinet $(\mathrm{PM} \& \mathrm{C})$ chaired by a Coordinator-General who in turn would work with Coordinators-General in each State and Territory. To ensure that the States did not cut back their own funding they were to report against "expenditure and output benchmarks" with the Heads of Treasuries charged with analysing this data "to ensure that existing effort by all jurisdictions is maintained" with final oversight by the Ministerial Council for Financial Relations (COAG 2009)

The pressure of the international crisis had seen Commonwealth-State relations revert to more familiar territory and the COAG process slip from the heady heights of March 2008 when it was at the core of a partnership for a new federalism, to being appropriated into a delivery agency for the Rudd government's desperate attempts to avoid an economic depression. Nevertheless, while the de-

3. This payment was to become the subject of a constitutional challenge in Australia's High Court See below

4. According to this account, as many of the components of stimulus package involved Commonwealth funding for state programs the Prime Minister wanted to be sure that the states did not cut back their own funding to let the Commonwealth "pick up the tab"

L'Europe en formation $n^{\circ} 358$ Hiver 2010 - Winter 2010 
cisions taken to avoid that depression highlighted the dominant role of the Commonwealth in economic management, their implementation also demonstrated the unavoidable role of the States and the necessity for some form of cooperative federalism. Similarly, the centrality of the States in the key areas of health and education meant that they would be central to any long term agenda for productivity and economic reform through the development of human capital.

\section{Government Borrowing: Commonwealth supremacy reasserted}

There was, however, one significant area of State activity that was dramatically affected by the global financial crisis and which, as a result, saw a realignment of Commonwealth and State roles and a reassertion of Commonwealth dominance. Government borrowing occupies a special place in the history of the Australian Federation (Saunders 1989: 197). The arrangements and rules that governed the borrowing of the States and the Commonwealth are encompassed within the Financial Agreement Act and the procedures of the Australian Loan Council. This system developed at the end of the 1920s and operated substantially unchanged for the almost the next seven decades of Federation giving the Commonwealth effective control of State borrowings. As such, it became an important contributor to the strengthening of the Commonwealth's position within the federation over the twentieth century. However, at the end of the 1980s, when the States were taking increasingly advantage of a deregulated financial system and easy access to global markets to bypass the formal controls imposed by the Loan Council, the Commonwealth turned to the markets for a solution. By 1993 the States were responsible for managing their own debt; the requirement for Commonwealth and State borrowing to be approved by the Loan Council and the Commonwealth's explicit power to borrow on behalf of the states had been removed, as was and the restriction on State's borrowing through the issue of securities in their own name.

This degree of independence ended suddenly on 25 March 2009 when the Treasurer announced that the Commonwealth would once again act as the guarantor of the borrowings of the States. The global recession had he said "threatened the capacity of state and territory governments to deliver critical infrastructure projects" and play their part in delivering reform to boost productivity (Swan 2009).

\section{Unintended consequences? The High Court, the GFC and the Powers of the Commonwealth}

While the GFC may not have sparked public discussion of Australian federalism, except for the warnings of business that it should not be allowed to get in the way of action by the central government, there was one forum in which the pow- 
ers of the Commonwealth to deal with the crisis were vigorously debated; this was the High Court of Australia. The occasion was Pape $v$ Commissioner of Taxation (HCA 2009) a case which revolved around the constitutionally validity of the direct payments to taxpayers under the Tax Bonus Act which formed part of the Commonwealth's 2009 stimulus package. The case had been brought by Bryan Pape a university lecturer and opponent of the centralisation of power within the Australian federation. ${ }^{5}$ The central issue pursued by Pape in his challenge to the legislation was the source and extent of the Commonwealth's power to spend money. The Commonwealth had long held the view that $s 81$ of the Constitution gave it power to spend "for the purposes of the Commonwealth" independent of any other specific authority in the Constitution. It had been supported in this stance by previous decisions of the Court (AGS 2009; 3). Initial reports of Mr Pape's challenge were met with and combination of wry amusement and mild derision. In attempting to stand between Australians and their cash handout media commentators suggested that he was "trying hard to be the most unpopular man in Australia" (Dick 2009).

A number of States ${ }^{6}$ indicated that they would seek to intervene - not because they opposed the payment, but to prevent what the NSW Attorney General described as the "unintended consequences" for Commonwealth-State relations which might arise from the expected Commonwealth argument that it was relying on its external affairs powers and an implied 'nationhood' power to deal with the economic crisis. Meanwhile the Australian Local Government Association (ALGA) expressed concern that any successful challenge to the Commonwealth's appropriation power might jeopardise direct grants to local councils (Sexton 2009b). The Court expeditiously delivered judgement on April 3, but provided its reasons some three months later on 7 July 2009 at which time it became clear that its decision was by no means clear cut (Saunders 2009 and McLeod 2010). The Court found by a 4:3 majority that the Tax Bonus Act, which provided for the payments, was valid. A further two Justices decided that it would be valid under the taxation power if 'read down' so that the payment was less than a person's adjusted tax liability, while one Justice found that it was entirely invalid.

In deciding that the payments were valid the Court relied on the Executive Power under s61 read in conjunction with the incidental power under s51(xxxix). The decision on Pape established that there must be a valid appropriation 'made by law' before money can be lawfully withdrawn to meet expenditure commit-

5. In 2005 Bryan Pape published "The Use and Abuse of Commonwealth Finance Power" in the Proceedings of the Samuel Griffith Society Volume 17 http://www.samuelgriffith.org.au/papers/html/volume17/v17chap9.html The Society is named after Sir Samuel Griffith who served as the Chief Justice of the High Court from 1903 until 1917 and who during those years, according to the Society's website, "consistently supported the rights of States against the powers of the federal Government" http://samuelgriffith.org.au/about-2/

6. New South Wales, Western Australia and South Australia

L'Europe en formation no3 358 Hiver 2010 - Winter 2010 
ments. The Court was unanimous in its rejection of the proposition that $s 81$ alone confers a power to spend and found that there must be a valid appropriation before money can lawfully be withdrawn from Treasury to meet expenditure commitments. In doing so it abandoned the distinction between 'spending' and 'engaging' which had been set out by the Court in the 1970s and which had been the basis for providing Constitutional legitimacy to Commonwealth spending programs in a wide range of areas (Saunders 2009: 260). However, against this relatively narrow interpretation of the power of the Commonwealth to spend the Court applied a broader interpretation of its Executive Power particularly in relation to action taken for the benefit of the nation in "novel" or "unusual" circumstances (McLeod 2010: 134). The Justices who formed the majority all accepted the view "with greater or lesser degrees of enthusiasm" (Saunders 2009: 261) that the nature of the global economic crisis meant that executive power extended to action to meet the adverse conditions which Australia faced. Concerns of the States that the Court might find a new applications for the interstate and overseas trade and commerce power, the external affairs power, or the implied 'nationhood' power were assuaged by the majority opinion that it was not necessary to deal with these powers and a further minority opinion that those heads of power could not be interpreted as supporting the Act (AGS 2009: 7).

The Chief Justice allowed that the Commonwealth could act in terms of the Executive Power for 'the proper purposes of national government', but he cautioned:

On the other hand, the exigencies of 'national government' cannot be invoked to set aside the distribution of powers between Commonwealth and States and between the three branches of government for which this Constitution provides, nor to abrogate constitutional prohibitions (HCA 2009: 127)

It was the view of the Chief Justice the tax bonus being "a short-term measure to meet an urgent national economic problem" did not interfere with the distribution of powers under the Constitution (HCA 2009:127).

The implications for federalism were seen as more acute for the Justices in the minority who argued that the constitutional questions were "deeper and more enduring than the particular and urgent circumstances that caused the enactment of the particular law" and transcended the immediate circumstances of the crisis (HCA 2009: 260). While the single Justice who dissented and found the Act invalid was more direct, dismissing the argument that the Commonwealth risked being "shrunken or crippled in its powers" and unable to deal with modern problems. The essential question, he said, and the essential aspect of federalism, was the division and dilution of power. Moreover: 
not all federations confer the same powers on their central governments. ... it is inherent in the idea of a federation that the central government has less power than the central government of a non-federation. It would be fallacious, and antithetical to the Constitution which created the federation, with its central and State governments, to ascribe to the central government automatically all powers which, in a non-federal nation, might be thought to be inherent in the fact of nationhood or in the idea of national government (HCA 2009 519).

Saunders (2009: 263) suggests that the judgement offers comfort for both the supporters of the division of powers within the federation and those wishing for a stronger central power. The constitutional fundamentals, including a federal division of powers, must be preserved, but the Commonwealth 'can take some heart' from the observation of the Chief Justice that the executive power offers constitutional support for national purposes which "may arguably extend to a range of subjects areas reflecting the established practice of the Commonwealth over a number of years" (as cited by Saunders 2009: 263).

However, the overall tenor of the judgement, the arguments advanced in the dissenting judgement, and the significant ruling in relation to s81 might also give heart to those standing against the centralisation of power in the Commonwealth. Certainly Brian Pape (2009:24) thought so summarising the implications of the judgement with the call to give " $[\mathrm{t}]$ hree cheers for the High Court". The Australian Local Government Association, which from the outset had expressed anxiety about the implications of the challenge to the legislation, was in no doubt that the judgement could restrain the Commonwealth. The Association received advice from constitutional lawyer Professor George Williams that the Court's decision confirmed that the Commonwealth did not have any general power to regulate or fund local government and that as a consequence a number of programs such as the National Building Roads to Recovery could be invalid. Williams (2009) suggested an amendment to $s 96$ which would specifically include the power to make grants to local government. The judgement has given new impetus to the campaign by the ALGA for a referendum to give local government constitutional status, which in Australia's current political environment appears to be winning support across both the major parties and the various independents 7 .

Other assessments suggested that it was not only the direct payments to local government which might be at risk in the event of a challenge. Commenting on the judgement, Duncan Kerr (2009: 315), Attorney General in the Keating Labor government, suggested that "[t]here are myriads of ways in which the Australian government currently spends money beyond that incidental to express Commonwealth heads of power". However, he played down the likelihood of a challenge,

7. The proposal for a referendum was part of the conditions the various independents put forward as the basis for gaining their support and has been accepted by the new Gillard minority Labor Government

L'Europe en formation no 358 Hiver 2010 - Winter 2010 
particularly as no State "looks remotely likely to want to grasp the potential Pape offers them to recontest the spending ground earlier claimed by the Commonwealth" (Kerr 2009: 319).

In large part the reason for the lack of public discussion on the wider implications of the Courts judgement in Pape reflects the paucity of debate on federalism in Australia, the conditional nature of the acceptance of the federal idea, and related to that the acceptance, particularly by the media and business groups, of the supremacy of the Commonwealth. However, the GFC did, if only for a short period, put the Constitution into play and did force public recognition of the essential federal nature of the Australian system of government. For the longer term the impact it less certain. Certainly the interpretation of $s 81$ is now clear and a restraint on the Commonwealth, while clarity regarding the extent of the executive power "awaits another case" (Saunders 2009:263).

\section{Conclusions}

The incoming Rudd government brought to an end what looked like an increasingly rapid spiralling of Commonwealth unilateralism and centralisation in the latter years of the Howard government. At the same time, the framework for a much more generally cooperative federalism introduced in 2007 through the COAG process, together with the Rudd government's program of reinvestment in public infrastructure and services that lay within State jurisdiction provided a ready vehicle for countercyclical policy activism in response to escalating symptoms of overseas financial crisis in 2008. The crisis reinforced centralising elements of the Rudd government's program, but in a muted way. More damaging for the State was the way that the crisis demonstrated their inherently weak fiscal position in the federation by exposing the fragility of their credit worthiness and the Triple A ratings they had proudly claimed over the previous two decades, in the absence of an implied guarantee from the Commonwealth and in the circumstances of the crisis a formal guarantee.

Against this the immediate response to the crisis, and the longer-term strategy to enhance productivity, highlighted that while the States have been relegated to the role of service delivery, this role remains significant in the national economy. The focus on human capital put State government responsibilities firmly at the centre of the government's reform agenda - as the focus on microeconomic reform did fifteen years earlier. The failure of the Commonwealth's attempt to go it alone and directly implement its ceiling insulation program also demonstrated the difficulties that a service delivery role can cause the central government. In a similar fashion they found their political fortune linked to the capacity of the States to deliver the programs they had mandated. 
Thanks to a combination of very active countercyclical policy and continuing high demand for its resource exports, Australia experienced no official recession and thus Commonwealth-State relations were not subject to the degree of strain they might have been in more extreme circumstances. At the same time, the High Court's surprisingly high degree of sensitivity to federalism in the Pape decision further limited the centralising impact of the crisis. Whether this decision will come to have a decisive impact on federalism will depend on future cases that may come before the Court.

As Australia moved clear of the impact of the crisis of 2008 towards a more certain economic outlook politics and government became less certain and for a time confused. The good fortune Australia enjoyed in avoiding prolonged recession did not transfer to the government that oversaw the implementation of the measures which added economic stimulus to good luck.

In large part this was of the government's own making. Five months short of the third anniversary his election victory, Kevin Rudd's role in shaping the federation ended as he acknowledged that he had lost the support of the Parliamentary Labor Party and stood down as Leader and as Prime Minister. In the months leading up to these dramatic events the federalist promise of the Rudd government had begun to fade in the face of political pressure that sought to cast it as a government of great intentions but little action. The politics of 2010 once again brought federalism to the fore as an election approached, but not this time as an opportunity for reform and repair of relationships between Canberra and the States. Decisions by the Commonwealth to establish a new national health and hospital system in place of the existing State-based arrangements - and in the process appropriate one third of the GST revenues on which the States so heavily relied - strained fraternal ties with the Labor States and saw the Coalition government of Western Australia reject Rudd's plan outright. Less than two months later, the announcement of the Resource Super Profits Tax cast doubt on the future of mining royalties levied by the states and brought the resource rich states of Queensland and Western Australia, and the aspiring resource rich state of South Australia, into open disagreement with the Commonwealth.

The electoral consequences of these decisions; the maladministration of the infrastructure programs which formed the stimulus package; and in particular the manner in which the Prime Minister was deposed proved to be a difficult legacy for his former Deputy and the new Prime Minister Julia Gillard. In the election that followed the leadership change Labor's majority was swept away. After 17 days of negotiations with the minor parties and independents who after the election held the balance of power Gillard clung to office by way of an alliance that gives her the barest margin of a one seat majority in the Parliament. 
It is not clear what impact the election result will have on the development of a more cooperative federal process. It is clear that a commitment has been made to hold a referendum to recognise local government within the Constitution, although the form of that recognition and the implications for Commonwealth powers to spend are as yet unknown. Substantial funding has also been promised to 'regional Australia' - which implies Commonwealth involvement within areas of state control, both physically and in terms of policy.

\section{REFERENCES}

AGS (Australian Government Solicitor) 2009 "Validity of Tax Bonus Payments Upheld: The Commonwealth's Power to Spend” Litigation Notes Number 1918 October, 1-7

Anderson, Geoff (2008) "The Council of Australian Governments: A New Institution of Governance for Australia's Conditional Federalism”, The University of New South Wales Law Journal, Vol. 31 No. 2 2008: pp. 493-508.

— 2010 "Whither the Federation? Federalism under Rudd Public Policy Volume 5 Number 1, 1-22

CA 2006 (Business Council of Australia), Reshaping Australia's Federation: A New Contract for Federal-State Relations <http://www.bca.com.au/DisplayFile.aspx?FileID=64> at 3 August 2008

BCA2009 (Business Council of Australia) "Global Downturn a New Challenge for Our Federation” Media Release 30 January http://www.bca.com.au/Content/101530.aspx

COAG 2007a (Council of Australian Governments) Communiqué Meeting 10 December, http://www.coag.gov.au/coag_meeting_outcomes/2007-12-20/index.cfm accessed 20 Octo

— 2007b (Council of Australian Governments) Communiqué Meeting 13 April http:// www.coag.gov.au/coag_meeting_outcomes/2007-04-13/index.cfm\#nra

- 2008 (Council of Australian Governments) Communiqué Meeting 26 March, http:// www.coag.gov.au/coag_meeting_outcomes/2008-03-26/index.cfm\#reform_agenda

- 2009 National Partnership Agreement on The Nation Building and Jobs Plan: Building Prosperity for the Future and Supporting Jobs Now 5 February http://www.coag.gov.au/ coag_meeting_outcomes/2009-02-05/docs/20090205_nation_building_jobs.pdf

Dick, Tom 2009 "Mission to stop manna from Kevin" The Sydney Morning Herald 30 Mark p. 11

Fenna, Alan. 2007a. The Division of Powers in Australian Federalism: subsidiarity and the single market. Public Policy 2 (3).

- 2007b. The Malaise of Federalism: comparative reflections on Commonwealth-State Relations. Australian Journal of Public Administration 66 (3):298-306.

- 2008. Commonwealth Fiscal Power and Australia Federalism. University of New South Wales Law Journal 31 (2):509-29.

2010. The Return of Keynesianism in Australia: the Rudd government and the lessons of recessions past. Australian Journal of Political Science 45(3).

Franklin, Matthew 2009 "States damaging PM" The Australian 30 January

Galligan, B \& D Mardiste (1992) “Labor's reconciliation with federalism”, Australian Journal of Political Science 27(special issue):71-86. 
Gillard, Julie 2008a Media release: Ministerial Council for Vocational and Technical Education Communiqué 21 November http://www.deewr.gov.au/Ministers/Gillard/ Media/Releases/Pages/Article_081128_094506.aspx accessed 5 August 2010

- 2008b "Priorities for the New Australian Government", Speech at the Australian and New Zealand Leadership Forum 13 June, available at http://www.pm.gov.au/node/5740 accessed 19 November 2009

Hawke, Allan 2010 Review of the Administration of the Home Insulation Program 6 April http://www.climatechange.gov.au/publications/energy-efficiency/home-insulation-hawke-report.aspx

HCA (High Court of Australia) (2009) Pape vs. Federal Commissioner of Taxation (2009) 257 ALR 1, 83 ALJR 765.

Kerr, Duncan (2009), Pape $v$ Commissioner of Taxation: Fresh Fields for Federalism?, Law and Justice Journal, Vol. 9, No. 2, 311-323.

McLeod, Andrew 2010 "The executive and financial powers of the Commonwealth: Pape v Commissioner of Taxation” Sydney law Review 32 (1) march 124-140

Pape, Bryan 2005 "The Use and Abuse of Commonwealth Finance Power" in the Proceedings of the Samuel Griffith Society Volume 17 http://samuelgriffith.org.au/

Pape, Bryan 2009 "The Tax Bonus case" in the Proceedings of the Samuel Griffith Society Volume 21 http://samuelgriffith.org.au/

Parkin, A \& V Marshall (1994) Frustrated, Reconciled or Divided? The Australian Labor Party and Federalism, Australian Journal of Political Science 29(1): p. 18-39.

Parkin, Andrew 2003 "The States, federalism and political science: a fifty-year appraisal". Australian Journal of Public Administration, v.62, no. 2, June 2003: pp. 101-112

Quiggin, John 2010 "Australia and the Global Financial Crisis" in Goodbye to all that? On the failure of neo-liberalism \& the urgency of change Edited by Robert Manne and David McKnight Black Link.Agenda Melbourne

Rudd, Kevin (2005) “The Case for Cooperative Federalism”, Address to the Don Dunstan Foundation - Queensland Chapter 14 July http://www.dunstan.org.au/resources/ lectures.html accessed 14 August 2010

— 2007, "Meeting of the Council of Australian Governments, Effective Federalism for the Future: Practical steps towards ending the blame game and boosting productivity growth" Media Release 10 December http://www.pm.gov.au accessed 16 November 2009

— 2008a "Towards a Productivity Revolution, A new Agenda of Micro-Economic Reform for Australia”, Address to the Australian/Melbourne Institute, New Agenda for Prosperity Conference, Melbourne University 27 March http://pandora.nla.gov.au/ pan/79983/20080512-0000/www.pm.gov.au/media/Speech/2008/speech_0148.html accessed 31 July 2010

- 2008b "Ministerial Statement: Economy" Parliamentary Debates House of Representatives 26 November pp 11504-11509

- 2008c, "Preparing Australia for Global Competitiveness in the 21st Century" Address to the 2008 Future Summit 11 May available at http://www.pm.gov.au/node/5803 accessed 19 November 2009

- 2009a Transcript: Prime Minister's Address to the Nation Parliament House, Canberra 3 February http://pandora.nla.gov.au/pan/79983/20090212-0444/www.pm.gov. au/media/Speech/2009/speech_0786.html accessed 5 August 2010 
- 2009b Transcript: Joint Press Conference of COAG Meeting Main Committee Room, Parliament House Canberra 9 February http://pandora.nla.gov.au/ pan/79983/20090212-0444/www.pm.gov.au/media/Interview/2009/interview_0795. html accessed 5 August 2010

— 2009c, "Energy Efficient Homes - Ceiling Insulation in 2.7 Million Homes" Media release by the Prime Minister 3 February http://www.pm.gov.au/node/5332 accessed 22 June 2010

Saunders, Cheryl 1989 "Government Borrowing in Australia," Melbourne University Law Review 17

- 2009 "The sources and scope of Commonwealth power to spend" Public Law Review 20 (4) December 256-263

- 2009 "States likely to intervene in bonus court case" The Sydney Morning Herald 20 March p7

Summers, John and Jan Lowe 2009, "The Federal System" in Government, Politics, and Power in Australia 9th Edition, Edited by Dennis Woodward, Andrew Parkin and John Summers, Pearson Australia Frenchs Forest 140-166

Swann, Wayne 2007 Transcript, Doorstop Interview Parliament House 18 December http://www.treasurer.gov.au/DisplayDocs.aspx?doc=transcripts/2007/004.htm\&pageI $\mathrm{D}=004 \& \mathrm{~min}=$ wms \&Year $=2007 \&$ DocType $=2$ accessed 5 August 2010

- 2008a "Ministerial Statement: Economy" Parliamentary Debates House of Representatives 18 March pp 2075-2078

- 2008b "Modern Federalism and Our National" Future Address to the 2008 Economic and Social Outlook Conference Melbourne 27 March http://www.treasurer.gov.au/DisplayDocs.aspx?doc=speeches $/ 2008 / 007 . h t m \&$ pageID $=005 \& \mathrm{~min}=$ wms $\&$ Year $=2008 \&$ DocType $=1$ accessed 5 August 2010

- 2009 "Temporary Guarantee of State borrowings" Media Release 25 March http:// www.treasurer.gov.au/DisplayDocs.aspx?doc=pressreleases $/ 2009 / 027 . h t m \&$ pageID = $\& \min =$ wms \&Year $=\&$ DocType $=0$ accessed 5 August 2010

Swann, Wayne and Lindsay Tanner 2009 Updated Economic and Fiscal Outlook February 2009 Canberra

Taylor, Lenore 2008 "States demand \$23bn as price of backing Rudd reform" The Australian 10 October $\mathrm{p} 1$

Taylor, Lenore and Uren, David 2010 Shitstorm Melbourne University Press Carlton

Wanna, John 2009 "Political Chronicles, Commonwealth of Australia July to December 2008" Australian Journal of Politics and History 55, 2 pp 261-315

Williams, George (2009) Advice to the Australian Local Government Association: Re: Pape $v$ Commissioner of Taxation and Direct Funding of Local Government" 12 August <http://www.councilreferendum.com.au/ $\geq$ accessed 13 August 2010

\footnotetext{
Abstract

The incoming Rudd government brought to an end what looked like an increasingly rapid spiralling of Commonwealth unilateralism and centralisation in the latter years of the Howard government. At the same time, the framework for a much more generally cooperative federalism introduced in 2007 provided a ready vehicle for countercyclical policy activism in response to escalating symptoms of overseas financial crisis in 2008. The crisis reinforced centralising elements of the government's program, but in a muted way. More damaging for the States was the way that the crisis demonstrated their inherently weak fiscal position in the federation.

Thanks to a combination of very active countercyclical policy and continuing high demand for its re-
} 
source exports, Australia experienced no official recession and thus Commonwealth-State relations were not subject to the degree of strain they might have been in more extreme circumstances. At the same time, the High Court's surprisingly high degree of sensitivity to federalism in the Pape decision further limited the centralising impact of the crisis. Whether this decision will come to have a decisive impact on federalism will depend on future cases that may come before the Court.

\section{Résumé}

Le nouveau gouvernement Rudd a mis fin à ce qui ressemblait de plus en plus à un unilatéralisme et une centralisation croissante du Commonwealth dans les dernières années du gouvernement Howard. Dans le même temps, le cadre d'un fédéralisme plus coopératif introduit en 2007 a fourni un instrument approprié à une politique anticyclique active, en réponse aux signes croissants venus du reste du monde d'une crise financière en 2008. La crise renforça les aspects centralisateurs du programme du gouvernement, mais de façon assourdie. Plus dommageable pour les États fut la façon dont la crise démontra leur faiblesse financière inhérente dans la fédération.

Grâce à une combinaison de politique anticyclique active et de demande élevée pour ses exportations, I'Australie ne vécut pas de récession officielle et les relations Commonwealth-États ne furent pas l'objet de tensions qui auraient pu apparaître en d'autres circonstances plus extrêmes. Au même moment, la surprenante sensibilité de la Haute Cour au fédéralisme dans la décision Pape limita encore l'impact centralisateur de la crise. Quant à savoir si cette décision aura un impact décisif sur le fédéralisme, cela dépendra des prochaines affaires qui pourraient être portées devant la Cour. 